\title{
Purificación y caracterización electroforética de la proteína de unión a GH (GHBP) en suero humano y de pacientes con cáncer y en embarazo: evidencia de la existencia de una proteína de unión a prolactina (PRLBP)
}

\author{
Elizabeth Rico ${ }^{1}$, Amílcar Flores ${ }^{2}$, Myriam Sánchez de Gómez ${ }^{1}$ \\ ${ }^{1}$ Laboratorio de Hormonas, Departamento de Química, Universidad Nacional de Colombia, Santa Fe de \\ Bogotá, D.C., Colombia. \\ ${ }^{2}$ Laboratorio de Endocrinología Molecular, Centro de Medicina Molecular, Hospital Karolinska, Estocolmo, \\ Suecia.
}

Una de las formas de regulación de la actividad de ciertas citocinas es la generación de formas solubles del receptor, las cuales actúan principalmente como proteínas de unión, aunque también se les han atribuido funciones de carácter agonista. El objetivo de este trabajo fue el de establecer la presencia de proteinas de unión a hormona de crecimiento (GHBP) y prolactina (PRLBP) en suero humano. La GHBP se purificó parcialmente mediante un nuevo método empleando hormona humana de crecimiento ( $\mathrm{GH}$, growth hormone) humana inmovilizada sobre Sepharosa y su separación y detección se realizó por medio de electroforesis e inmunotransferencia (Western blot), utilizando un anticuerpo dirigido contra el receptor de $\mathrm{GH}$. Los resultados mostraron que la GHBP de suero humano es una mezcla compleja de proteínas con pesos en el rango de 27 a $62 \mathrm{kDa}$, relacionadas estructuralmente con el receptor de $\mathrm{GH}$ y cuyo origen está por determinarse. El suero proveniente de pacientes con cáncer de seno en estados 3 y 4 , así como el de embarazo, mostró el mismo perfil de proteínas aunque sus niveles fueron en todos los casos inferiores a la normalidad, siendo los más bajos los de embarazo. En cuanto a la PRLBP, mediante anticuerpos antirreceptor, se identificó una proteína sérica de $150 \mathrm{kDa}$ disociable en dos subunidades de pesos 50 y 30 $\mathrm{kDa}$, consistente con lo informado por otros autores. De acuerdo con el peso establecido y a su incapacidad para unir hGH, se concluyó que no es una forma soluble del receptor y se sugiere que puede ser un anticuerpo antiidiotípico presente en suero humano. No se encontraron diferencias en el perfil ni en el contenido de la PRLBP en los tres tipos de suero analizados. Los resultados obtenidos ponen en evidencia la existencia de una proteína de unión a prolactina relacionada con el receptor de PRL y cuyo origen en humanos está por establecerse.

Palabras clave: proteína de unión a hormona de crecimiento (GHBP), proteína de unión a prolactina (PRLBP), cáncer de seno.

Purification and electrophoretic characterization of growth hormone binding protein (GHBP) in human, cancer and pregnancy sera: evidence of the presence of prolactin binding protein (PRLBP)

Control of cytokine activity is provided in certain cases by the generation of soluble forms of the receptor, which mainly function as binding proteins, although some other agonistic properties have been described. The objective of the present study was to identify the growth hormone binding protein (GHBP) and the prolactin binding protein (PRLBP) in human serum. GHBP was partially purified by a new method using Sepharose-immobilized $\mathrm{hGH}$ and separated and detected by electrophoresis and immunotransference (Western blot) using an antibody against the $\mathrm{GH}$ receptor. We found that human serum GHBP is a complex mixture of proteins with molecular weights in the range of 27 to $62 \mathrm{kDa}$, structurally related to the receptor and whose origin is still unknown. Sera from breast cancer patients and pregnant subjects showed the 
same protein profile although the levels were lower than the normal ones, those in pregnant subjects being the lowest. A $150 \mathrm{kDa}$ protein, which dissociates into two subunits of 50 and 30 $\mathrm{kDa}$, was identified by an anti-PRL receptor antibody, consistent with previous reports. According to the molecular weight and the lack of hGH binding activity observed, it is likely that the protein is not a soluble form of the receptor but might be an anti-idiotipic antibody in human serum. No differences in the protein profile were observed in the three sera investigated. The results suggest the presence of a prolactin binding protein, related to the receptor and whose origin awaits further studies.

Key words: growth hormone binding protein (GHBP), prolactin binding protein (PRLBP), breast cancer.

La prolactina (PRL) y la hormona de crecimiento (GH) son proteínas que presentan semejanza estructural y pertenecen a la familia de proteínas HBP (helix bundle protein), junto con factores de crecimiento y algunas interleucinas (1). Estas proteínas son segregadas principalmente por células especializadas en la hipófisis (2), para luego ser liberadas en el torrente sanguíneo y actuar de forma endocrina en los tejidos blanco. Se le han atribuido muchas funciones a la prolactina, entre las que se cuentan la regulación del desarrollo de la glándula mamaria, la modulación de la respuesta inmune y la iniciación y el mantenimiento de la lactancia (3). Como su nombre lo indica, la función principal de la hormona de crecimiento es el desarrollo y crecimiento de vertebrados, específicamente el crecimiento longitudinal del hueso (4).

Todas estas funciones son iniciadas por la unión de la hormona a su receptor específico de membrana (5). Los receptores para estas hormonas pertenecen a la superfamilia de receptores de citocinas, en los cuales, además, se encuentran los receptores del factor inhibidor de leucemia (LIF), del factor de necrosis tumoral (TNF), la oncostatina $M y$ algunas interleucinas (6-7).

Se han identificado tres isoformas para el receptor de prolactina, las cuales son idénticas en los dominios transmembrana y extracelular pero varían en la longitud del dominio citoplasmático, dando lugar a las denominadas forma larga, $\mathrm{Nb2}$ y corta $(8,9)$. En el caso del receptor de GH se han identificado dos isoformas, en las que la

\section{Correspondencia:}

Myriam Sánchez de Gómez, Departamento de Química, Universidad Nacional, Santa Fe de Bogotá, D.C., Colombia, email:mygomez@ciencias.ciencias.unal.edu.co

Recibido: 04/08/99; aceptado: 31/03/00 forma mayoritaria codifica para una proteína de 90 kDa (10-11). Esta familia de receptores presenta algunas características estructurales comunes y son los principales intermediarios en la transducción de la señal activada por el ligando (6). Dentro de la vías más estudiadas se encuentra la vía JAK-STAT, la cual es empleada por casi todas las proteínas que pertenecen a la familia HBP, incluidas la hormona de crecimiento y la prolactina (12). Una de las formas de regulación de la actividad de ciertas citocinas es la generación de formas solubles del receptor, las cuales actúan en su mayoría como proteínas de unión (transportadoras), inhibiendo la unión del ligando a su receptor de membrana (13-15). Sin embargo, se han atribuido a estas proteínas otras funciones de carácter agonista, como son el incremento en la estabilidad del ligando, la disminución de la degradación y el aumento de la vida media del mismo (15).

La hormona de crecimiento se encuentra en la circulación principalmente enlazada a dos proteínas de unión de alta y baja afinidad, de las cuales la de mayor afinidad corresponde al dominio extracelular del receptor (16) que es generada por proteólisis del receptor en humanos (17-18) y por splicing alternativo en roedores (19). Esta proteína tiene importantes implicaciones en la distribución y en las acciones fisiológicas de la GH. Para la prolactina, se ha identificado una proteína de unión en leche de conejo (20) y en leche humana (21), que probablemente corresponden al dominio extracelular del receptor de prolactina. En suero humano (22) y de rata (23), se ha detectado una proteína con capacidad de unión a la prolactina, pero que, de acuerdo con el peso encontrado y la secuencia en su estructura primaria, no corresponde al dominio extracelular del receptor. 
La hormona de crecimiento y la prolactina han sido relacionadas con el cáncer de seno y el embarazo. Se ha encontrado que las pacientes con cáncer de seno presentan una concentración elevada de hormona de crecimiento (24) y que las líneas celulares de cáncer mamario (MCF-7 y T47D) tienen un elevado número de receptores de prolactina (25). Se ha establecido, además, el carácter mitogénico de la prolactina y de la hormona de crecimiento en líneas celulares derivadas de cáncer de seno y en cultivos primarios (26), en tanto que en embarazo, el crecimiento del feto está fundamentalmente regulado por la variante para la hormona de crecimiento ( $\mathrm{hGH}-\mathrm{V}$ ), la cual presenta una pequeña diferencia estructural con la forma normal y cuya concentración se incrementa en la gestación (27). La prolactina, como se dijo antes, está directamente involucrada con la preparación de la glándula mamaria para la lactancia.

En este estudio se pretendió establecer el perfil electroforético para las GHBP y PRLBP en suero humano y de mujeres en embarazo y con cáncer de seno, empleando un nuevo método de purificación con hGH-inmovilizada en Sepharosa. Se investigaron las posibles variaciones en el perfil electroforético en los tres tipos de suero.

\section{Materiales y métodos}

\section{Sueros}

Se analizaron 10 muestras de suero para cada uno de los siguientes grupos de estudio:

1) mujeres con cáncer de seno en estados 3 y 4 (metástasis) sin ningún tratamiento previo, con edades entre 30 y 60 años y que asisten a consulta en el Instituto Nacional de Cancerología de Santa Fe de Bogotá;

2) mujeres en estado de embarazo, con edades entre 15 y 18 años, y

3) mujeres sin ninguna patología del seno, que se utilizaron como controles.

Todos los sueros se tomaron con el consentimiento previo de las personas, sin estar en ayuno. Para los análisis, se hicieron mezclas o pools de cada uno de los grupos de estudio.

\section{Anticuerpos}

Se utilizaron los siguientes:

- U5, anticuerpo monoclonal dirigido contra el dominio extracelular del receptor de prolactina de rata (Affinity Bioreagents, Inglaterra);

- GHR26, anticuerpo monoclonal contra el receptor de hormona de crecimiento (Pharmacia, Suecia);

-antilgG-ratón conjugado a peroxidasa (Amersham, Inglaterra);

- T6 y Mab7c3, anticuerpos monoclonales contra el receptor de $P R L$ de rata;

- anti-PRL policlonal contra el PRLR obtenido en gallina.

\section{Estándares}

Se utilizaron los siguientes:

- proteina de unión a PRL recombinante (rPRLBP), (Pharmacia, Suecia);

- proteína de unión a $\mathrm{GH}$ recombinante (rGHBP), (Pharmacia, Suecia), y

- GH-Sepharosa, (Pharmacia, Suecia).

\section{Detección de la proteína de unión a prolactina en suero}

La detección de la proteína de unión a PRL en suero se llevó a cabo por Western blot, usando como primer anticuerpo el U5, el cual reacciona con los receptores de prolactina humanos. El contenido de proteína se determinó por el método de Bradford (28). La metodología empleada se basó en la utilizada por Maaskant (29), con algunas modificaciones. Las proteínas presentes en el suero se separaron electroforéticamente, en condiciones reductoras y no reductoras, en geles de poliacrilamida al 12 y $10 \%$, respectivamente. Luego, las proteínas se inmovilizaron por transferencia a membranas de nitrocelulosa $(0,2 \mu \mathrm{m})$ y se incubaron durante toda la noche a $4{ }^{\circ} \mathrm{C}$ en TBS (buffer tris-salino, $\mathrm{pH} 7,4$ ) que contenía BSA (albúmina sérica bovina) al $1 \%$. La membrana se incubó con el primer anticuerpo U5 $(1 \mathrm{mg} / \mathrm{ml})$ en TTBS-BSA 1\% (buffer tris-salino con Tween y $B S A$ ), durante una hora a temperatura ambiente, seguido por tres lavados con TTBS. La incubación con el segundo anticuerpo (anti-IgG ratón conjugado a peroxidasa) se realizó durante una hora a temperatura ambiente usando una dilución 1:3.000 y se preparó en las mismas condiciones empleadas para el primer anticuerpo. Luego, se realizaron 4 lavados con TTBS y se reveló la membrana por quimioluminiscencia de acuerdo con las instrucciones del fabricante (Enhancer Chemiluminiscence, Amersham). 


\section{Evaluación de la capacidad de unión de la resina}

Se realizaron ensayos de unión con rhGHBP (proteína de unión a GH recombinante humana) marcada radioactivamente en presencia de buffer de unión $\left(\mathrm{PO}_{4}^{3-}, 10 \mathrm{mM}, \mathrm{pH} 7,4, \mathrm{MgCl}_{2} 75 \mathrm{mM}\right.$, $\mathrm{ZnCl}_{2} 50 \mathrm{mM}$ y BSA $1 \%$ ). La proteína recombinante se incubó con la resina durante toda la noche a 4 ${ }^{\circ} \mathrm{C}$ o por dos horas a $37^{\circ} \mathrm{C}$ con agitación moderada. Luego, se centrifugó a 3.000 rpm durante 5 minutos; se aspiró el sobrenadante y el precipitado se lavó tres veces con PBS y, finalmente, se contó en un contador de rayos gamma. Se evaluaron concentraciones de 1,10 y $50 \%$ y volúmenes de 1,10 y $100 \mathrm{ml}$ de resina.

\section{Detección de la proteína de unión a hormona de crecimiento}

Con base en las condiciones evaluadas previamente, se empleó cromatografía de afinidad con hGH-Sepharosa para la purificación de la proteína de unión a hormona de crecimiento en suero humano. Las muestras de suero $(2 \mathrm{ml})$ se incubaron con $750 \mathrm{ml}$ de la resina $(50 \%)$ en presencia de $\mathrm{PO}_{4}{ }^{3-}(10 \mathrm{mM}), \mathrm{MgCl}_{2}(75 \mathrm{mM})$ y $\mathrm{ZnCl}_{2}(50 \mathrm{mM})$, $\mathrm{pH} 7,4$ e inhibidores de proteasas durante toda la noche a $4^{\circ} \mathrm{C}$ con agitación constante. Luego, se centrifugó a 3.000 rpm por 10 minutos y se lavó con PBS (tres veces). Se adicionaron $100 \mathrm{ml}$ de buffer Laemmli en presencia o ausencia de $\beta-\mathrm{ME}$ a las muestras, se calentaron y se centrifugaron

A
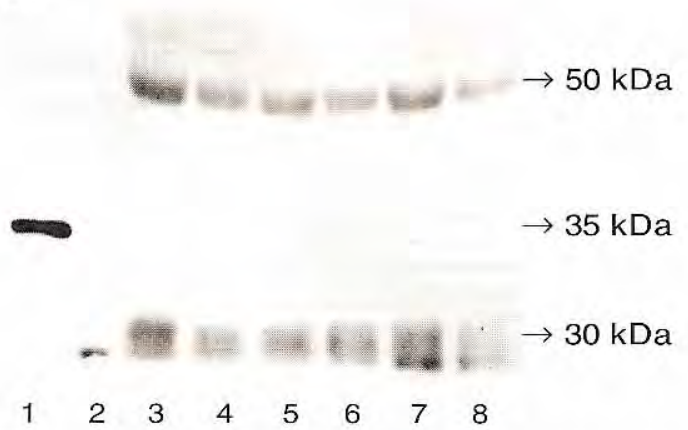

a 14.000 rpm durante un minuto. El sobrenadante se aplicó a un gel de poliacrilamida al $12 \%$ y después de la electroforesis se transfirieron las proteínas a membranas de nitrocelulosa $(0,2 \mu \mathrm{m})$. Las membranas se bloquearon con leche descremada al $5 \%$ en TBS durante 1 hora a temperatura ambiente; se incubó durante una hora con el anticuerpo contra el receptor de hormona de crecimiento (GHR26), preparado en TTBS que contenía leche al $1 \%$. El revelado se realizó como se describió en el numeral anterior.

\section{Resultados}

\section{Determinación de la proteína de unión a prolactina}

En la figura 1 se muestran los resultados del análisis por Western blot de la proteína de unión a prolactina, utilizando como primer anticuerpo el U5.

Como se puede observar, por medio de Western blot se detectó una proteína de aproximadamente $150 \mathrm{kDa}$ en condiciones no reductoras y dos de 50 y $30 \mathrm{kDa}$, aproximadamente, en condiciones reductoras y no se detectaron diferencias apreciables entre las muestras de pacientes con cáncer de mama y los controles. Las membranas se probaron con otros tres anticuerpos (T6, Mab 7c3, anti-PRLR policlonal) todos dirigidos contra el receptor de prolactina, encontrándose los mismos resultados, aunque como se observa en la figura 2 , con los anticuerpos Mab7c3 y policlonal no se logró el mismo nivel de detección, posiblemente

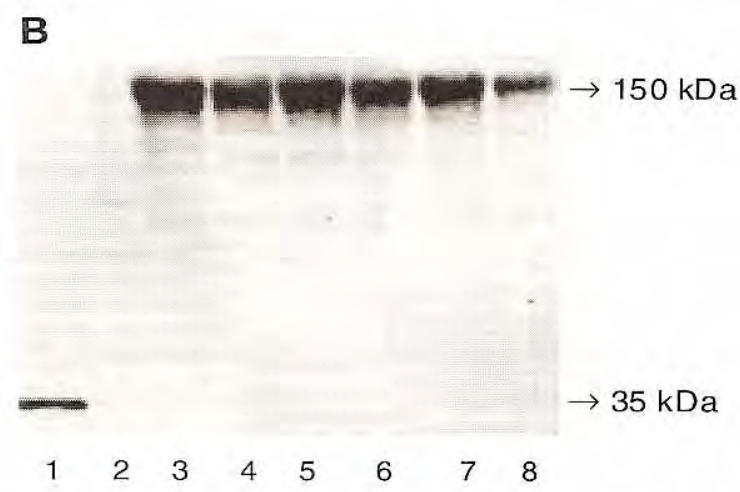

Figura 1. Identificación de la PRLBP de suero humano por Western blot. Se separaron electroforéticamente muestras de suero de pacientes con cáncer de seno y controles en geles de poliacrilamida tal como se describe en los métodos. A) Condiciones reductoras; B) condiciones no reductoras; carril 1: PRLBP recombinante; 2, patrón de PM; 3, 4 y 5, sueros malignos; 6,7 y 8 , sueros controles. El ensayo es representativo de tres realizados en las mismas condiciones. 
U 5

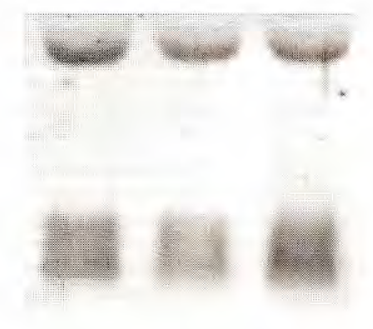

T6

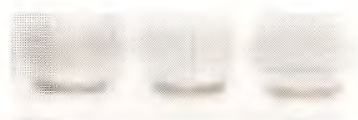

Mab $7 \mathrm{c} 3$

$\rightarrow 50 \mathrm{kDa}$

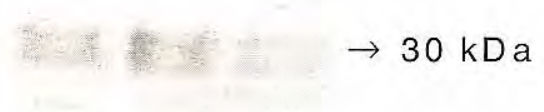

anti-PRLR

policlonal

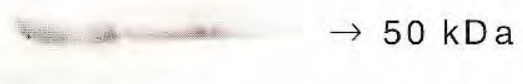

$\rightarrow 30 \mathrm{kDa}$

123

Figura 2. Identificación de la PRLBP en suero humano por Western blot. Se separó electroforéticamente suero de mujeres sanas (carril 1), con cáncer de seno (carril 2) y en embarazo (carril 3), y se analizaron por WB tal como se describe en la metodología y se revelaron con cuatro anticuerpos dirigidos todos contra PRLR.

por la dilución empleada. Como control positivo, se empleó la proteína de unión a PRL recombinante acoplada a proteína $A$, con un peso de $35 \mathrm{kDa}$ (Pharmacia, Suecia).

\section{Evaluación de la actividad de la resina hGH-Sepharosa}

En el cuadro 1 se puede observar la capacidad de la resina para reconocer la proteína de unión a GH humana recombinante, así como las mejores

Cuadro 1. Evaluación de la capacidad de unión de la resina hGH-Sepharosa. Se evaluaron tres condiciones de resina $(1,10$ y $50 \%$ ) y dos condiciones de incubación tal como se describe en los métodos. Los resultados se muestran como el promedio \pm desviación estándar.

\begin{tabular}{crrr}
\hline $\begin{array}{c}\text { Resina } \\
\%\end{array}$ & $\begin{array}{c}\text { Volumen } \\
(\mu \mathrm{l})\end{array}$ & $\begin{array}{r}37^{\circ} \mathrm{C}, 4 \mathrm{~h} \\
\% \text { unión }\end{array}$ & $\begin{array}{r}4^{\circ} \mathrm{C}, 18 \mathrm{~h} \\
\% \text { unión }\end{array}$ \\
\hline \multirow{2}{*}{1} & 1 & $0,83 \pm 1,58$ & $1,11 \pm 0,47$ \\
& 10 & $8,57 \pm 1,15$ & $17,74 \pm 5,73$ \\
& 100 & $40,26 \pm 7,04$ & $51,12 \pm 16,04$ \\
10 & 1 & $9,32 \pm 1,72$ & $7,58 \pm 4,42$ \\
& 10 & $49,66 \pm 9,25$ & $55,54 \pm 6,08$ \\
& 100 & $55,52 \pm 0,40$ & $41,84 \pm 7,31$ \\
50 & 1 & $5,38 \pm 5,04$ & $-\cdots$ \\
& 10 & $11,71 \pm 2,48$ & $-\cdots$ \\
& 100 & $50,83 \pm 3,34$ & - \\
\hline
\end{tabular}

condiciones para realizar la purificación de la proteína.

Al incrementar la concentración de la resina y su volumen, la capacidad de unión de la resina aumenta como es de esperar, siendo las mejores condiciones, en todos los casos, la incubación realizada a $4^{\circ} \mathrm{C}$ durante toda la noche y con agitación moderada.

\section{Determinación de la proteína de unión a $G H$}

Para su detección, se realizó la purificación parcial de la proteína, haciendo uso de la capacidad de unión de la proteína (GHBP) a hGH. Para ello, se utilizó una resina preparada acoplando establemente hGH a Sepharosa, la cual se evaluó previamente. Como control positivo en el Western blot, se empleó proteína de unión a $\mathrm{GH}$ recombinante con un peso de $30 \mathrm{kDa}$. Las figuras 3 y 4 muestran los resultados obtenidos en suero normal, de cáncer de seno y de embarazo. Se ensayó también la purificación de la PRLBP con esta resina de afinidad, pero no se obtuvieron resultados positivos (estos resultados no se muestran).

Como se observa, mediante este sistema de afinidad es posible separar electroforéticamente la 

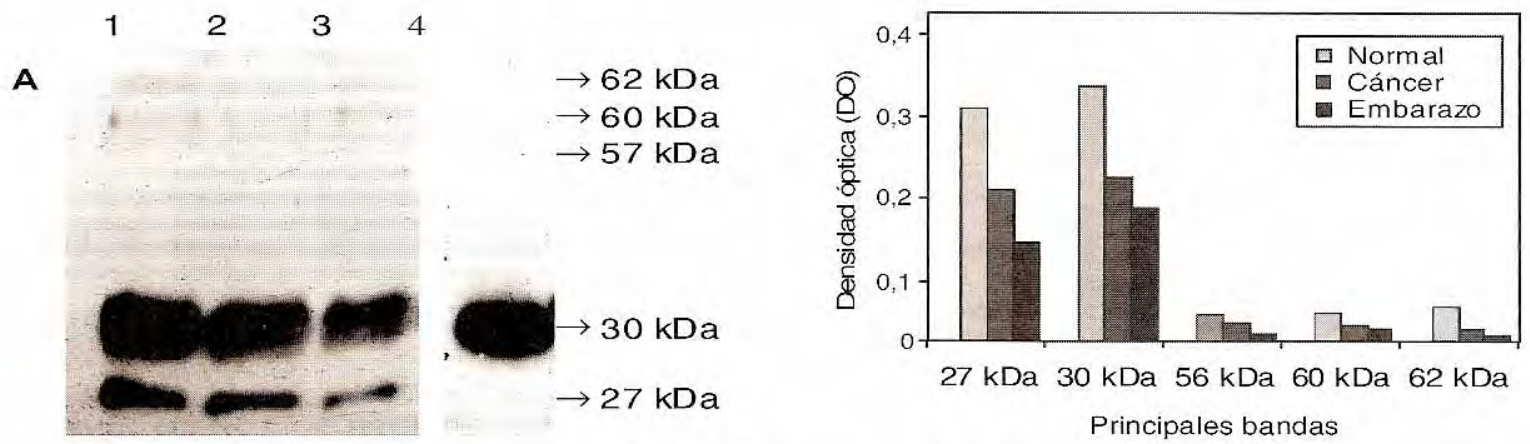

Figura 3. Purificación y separación de las variantes de GHBP en suero humano en condiciones reductoras. Se purificaron sueros normal, de cáncer de seno y de embarazo $(2 \mathrm{ml})$ con hGH-Sepharosa y se separaron por electroforesis tal como se describe en los métodos. La membrana se probó con un anticuerpo dirigido contra el receptor de hormona de crecimiento (GHR26) y la intensidad de las bandas se midió en un densitómetro; carriles: 1; normal; 2, cáncer; y 3, embarazo; 4, GHBP recombinante.
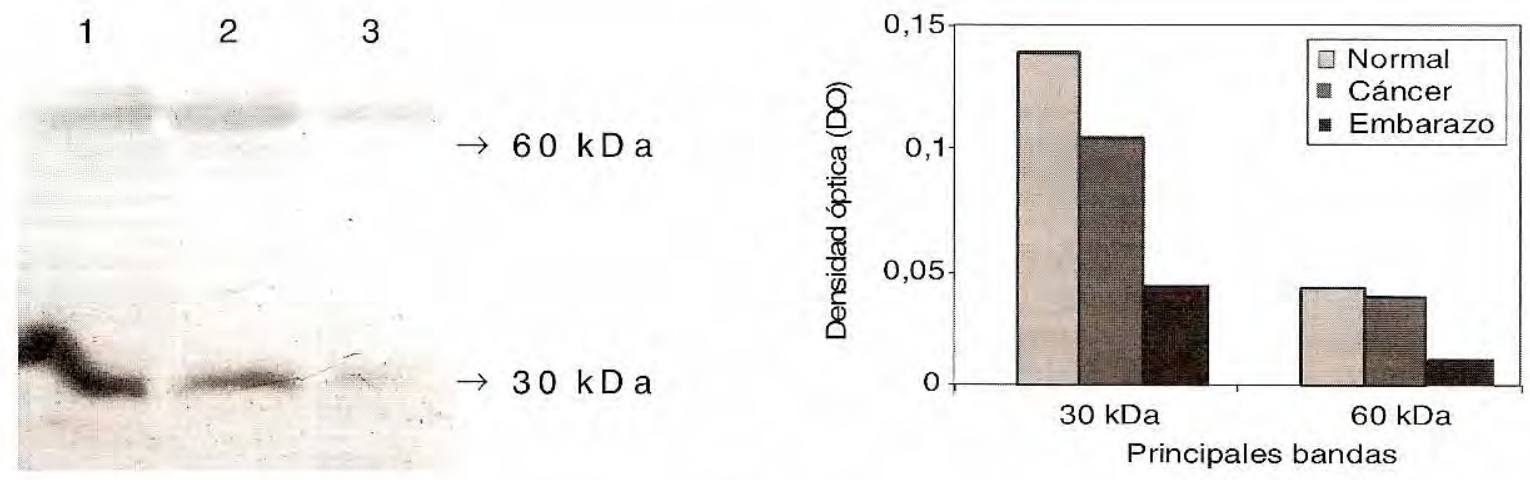

Figura 4. Purificación y separación de las variantes de GHBP en suero humano en condiciones no reductoras. Se purificaron sueros normal, de cáncer de seno y de embarazo $(2 \mathrm{ml})$ con hGH-Sepharosa y se separaron por electroforesis tal como se describe en los métodos. La membrana se probó con un anticuerpo dirigido contra el receptor de hormona de crecimiento (ghr26) y la intensidad de las bandas se midió en un densitómetro; carriles: 1, normal; 2, cáncer; y 3 , embarazo.

GHBP y sus variantes a partir de suero humano. El análisis densitométrico mostró variaciones en la intensidad de las bandas para cada tipo de suero, siendo el suero normal el de mayor contenido. La proteína de unión a $\mathrm{GH}$ en plasma humano fue identificada por Baumann en 1986 (30), como una forma soluble del receptor de $\mathrm{GH}$, altamente glicosilada y con un peso de $60 \mathrm{kDa}$ correspondiente al encontrado en nuestra purificación. Sin embargo, como se observa en la figura 3, una banda de mayor intensidad y con un peso de $30 \mathrm{kDa}$ se detectó en todas las purificaciones realizadas. Para comprobar la especificidad del anticuerpo utilizado y descartar la posibilidad de que esta proteína de bajo peso molecular fuera inespecífica, las membranas se analizaron nuevamente con el segundo anticuerpo y con el anticuerpo U5 (antiPRLR), encontrándose que estos anticuerpos no reconocen esta banda, lo que indica que se trata de una proteína relacionada con el receptor de GH. Así mismo, se evaluó la reacción cruzada del anticuerpo GHR26 con la proteína de unión a prolactina, con prolactina y con hormona de crecimiento, sin encontrarse reacción cruzada con ninguno de los ligandos evaluados.

\section{Discusión}

El estado hormonal es uno de los muchos factores que están directamente involucrados con el riesgo y la evolución del cáncer de seno. Se han 
involucrado hormonas como la prolactina, la hormona de crecimiento y sus respectivos receptores (31). La identificación de las diferentes isoformas para los receptores de prolactina (32) y para la hormona de crecimiento (33) han sido descritos en líneas celulares derivadas de cáncer mamario y en cultivos primarios. Un mecanismo utilizado por algunas citocinas, incluida la hormona de crecimiento, para mantener el control celular se realiza mediante la generación de formas solubles de sus receptores, las cuales retienen la capacidad de unión a sus respectivos ligandos y permiten modificar la concentración libre del ligando, actuar como proteínas estabilizadoras y transportadoras e inhibir la asociación ligando/ receptor.

Hace ya algunos años, se evidenció la existencia de proteínas de unión para GH y para prolactina en suero humano. El papel exacto que desempeñan estas proteínas en suero no ha sido aún completamente elucidado, de ahí la importancia de determinar las variaciones en los niveles de las proteínas de unión en condiciones donde las hormonas tienen un papel fisiológico establecido. Como se observa en la figura 1, en las muestras estudiadas se detectó una proteína que es reconocida por 4 anticuerpos específicos contra el receptor de prolactina. Esta proteína presenta un peso de $150 \mathrm{kDa}$ en condiciones no reductoras y se separa en dos subunidades de 50 y $30 \mathrm{kDa}$ en condiciones reductoras. De acuerdo con los pesos obtenidos en este trabajo y en algunos previos, la proteína circulante puede estar formada por cuatro subunidades: 2 de 50 $\mathrm{kDa}$ y 2 de $30 \mathrm{kDa}$, unidas entre sí por puentes disulfuro (23), las cuales podrían corresponder a las cadenas pesada y liviana de IgG (22).

Aunque la capacidad de unión de la proteína no se probó en este trabajo, otros autores han determinado que una inmunoglobulina con características semejantes a las aquí descritas tiene capacidad de unión por prolactina humana a través de la subunidad de $50 \mathrm{kDa}(22,34)$. Los anticuerpos utilizados para la determinación de esta proteína, reconocen todas las isoformas del receptor de prolactina y no presentan reacción cruzada con el receptor de $\mathrm{GH}$, que es la proteína estructuralmente más cercana al receptor de PRL; por tanto, se presume que la proteína identificada en los sueros analizados presenta una estrecha relación con el receptor de prolactina. Estudios realizados en ratas macho y hembra tratadas con $E_{2}$ benzoato, el cual es un agente que incrementa el nivel circulante de PRL, presentan un mayor nivel de proteína de unión en comparación con las ratas no tratadas (23). Los altos niveles de receptor de prolactina en la glándula mamaria durante la lactancia están probablemente relacionados con la existencia de proteínas de unión en la leche materna.

De acuerdo con la figura 2, la proteína identificada en los sueros no presenta cambios apreciables ni en su naturaleza ni concentración en los diferentes grupos estudiados. Se podría pensar que debido al aumento en el nivel de receptores de prolactina en pacientes con cáncer de seno y en estado de embarazo, así como el nivel sérico de la hormona, podría llevar a un aumento en la concentración de la proteína de unión. Este hecho, unido a la incapacidad para purificar esta proteína utilizando $\mathrm{hGH}$, un conocido ligando del receptor de PRL, y al peso molecular detectado, permiten concluir que esta proteína no es idéntica al dominio extracelular del receptor, aunque estructural-mente pueden estar relacionadas. La cuantificación de la proteína de unión en las muestras biológicas, así como la determinación de los niveles de PRL libre y total será de gran ayuda en la elucidación del papel de estas proteínas en pacientes con diferentes condiciones clínicas.

Para la hormona de crecimiento, se han identificado dos proteínas de unión, una de alta y otra de baja afinidad (16), de las cuales la proteína de alta afinidad corresponde al dominio extracelular del receptor con un alto grado de glicosilación. Esta proteína de unión (GHBP) ha sido aceptada como un miembro más en el eje GH/IGF-I. Los niveles séricos de GHBP han servido como un indicador de anormalidades en el eje de $\mathrm{GH}$, ya que la determinación del nivel de receptores de $\mathrm{GH}$ en humanos es casi imposible (17). Esta proteína presenta un peso de $60 \mathrm{kDa}$ y ha sido determinada en suero humano (18), de mico (35), de rata (36), células IM9 (37), condrocitos (38) y células Hep G2 (39), línea celular de hepatoma humano, así como en líneas celulares 
que han sido transfectadas con el cADN que codifica para el receptor de $\mathrm{GH}$ de conejo (40). A esta hormona se le han atribuido muchas funciones como disminuir la depuración metabólica de $\mathrm{GH}$ prolongando su vida media, modular la cantidad de GH libre y unida y la unión de la hormona a su receptor de membrana (17). Los efectos netos de la acción de la proteína de unión se pueden reflejar en el aumento de la acción biológica de la hormona (efecto agonista) o en la inhibición de la misma (efecto antagonista), aunque esta última no es la acción más común in vivo (41).

Como se observa en la figura 3, el método descrito en este trabajo permitió la purificación parcial y separación por electroforesis de la proteína de unión a GH en sueros humanos, cuyo peso oscila entre 27 y $62 \mathrm{kDa}$. De acuerdo con la secuencia esperada para el dominio extracelular del receptor en ratones, el peso de la proteína de unión sería de 29-30 kDa; sin embargo, todos los estudios realizados al respecto hasta el momento indican que el mayor peso molecular de la GHBP se debe a un alto grado de glicosilación, lo que explica la variación en los pesos encontrados. En suero humano, la banda principal es de $60 \mathrm{kDa}$, pero diferentes estudios han podido detectar isoformas para esta proteína con pesos de $55 \mathrm{kDa}$ y $32 \mathrm{kDa}(10)$.

Observando los resultados obtenidos en la purificación parcial utilizando hGH-Sepharosa, la proteína de unión a $\mathrm{GH}$ en suero humano en condiciones reductoras presenta presumiblemente las formas glicosiladas (bandas de 60 y $57 \mathrm{kDa}$ ) y otras con un menor grado de glicosilación (bandas de $30 \mathrm{kDa}$ y $27 \mathrm{kDa}$ ). Se sugiere que estas últimas pueden deberse también a proteólisis de la proteína de mayor peso molecular, conservándose la región de unión al ligando y el epítope reconocido por el anticuerpo empleado en su detección.

Cuando se realiza el ensayo de purificación en condiciones no reductoras (figura 4), se obtienen las bandas de 60 y $30 \mathrm{kDa}$, pero esta última presenta una menor intensidad. Esto puede deberse a que la ausencia de agente reductor no permite la total liberación de la proteína de unión ligada a la resina. Sin embargo, la banda de alto peso molecular sigue estando presente.

De acuerdo con la intensidad de las bandas presentes en las figuras 3 y 4 , se presentan algunas diferencias entre las muestras control, los sueros de pacientes con cáncer y en embarazo. La intensidad para las bandas de alto y bajo peso molecular en los sueros control son mayores que en las otras dos muestras estudiadas. Se ha descrito que la concentración de GHBP en sangre presenta variaciones de acuerdo con la especie y con el estado fisiológico. En ratones, se sabe que el nivel del mARN que codifica para la GHBP es elevado en estado de embarazo, en tejidos como el hígado, donde se presenta un aumento de cerca de 20 veces en comparación con el control, lo que sugiere un fuerte papel de la GHBP en ratones normales en embarazo (42). Sin embargo, recientes estudios indican que existe una relación inversa entre la concentración sérica de $\mathrm{GH}$ y GHBP (41).

El embarazo en humanos causa un incremento en el contenido de GH sanguíneo con un leve incremento inicial en el nivel de GHBP que luego se ve disminuido (27). Esto indica que la disminución en el nivel de GHBP podría estar causando un aumento en la porción disponible de $\mathrm{GH}$ y que de esta forma aumentaría la acción biológica de la hormona. Se sabe, además, que la concentración materna en placenta de la variable de $\mathrm{GH}$ $(\mathrm{hGH}-\mathrm{V})$ se incrementa a través de la gestación y que es la hormona que en principio afecta más directamente el crecimiento fetal por lo que debe estar en forma libre para poder unirse a su receptor e iniciar su actividad biológica.

La hormona de crecimiento ha sido involucrada con el desarrollo normal de la glándula mamaria (43) y aunque la relación existente entre el cáncer de seno y la hormona de crecimiento ha sido un poco menos estudiada, se sabe que los niveles de $\mathrm{GH}$ en suero de mujeres con cáncer se encuentran elevados (24). Además, se han detectado dos isoformas para el receptor de $\mathrm{GH}$ en líneas celulares de cáncer mamario (MCF-7 y T47D) y tejidos, lo cual sugiere una acción específica en el desarrollo de tumores (33). Al igual que para las muestras de embarazo, el nivel de 
GHBP es menor en las muestras de pacientes con cáncer en comparación con el control (figura 3). Hasta el momento, no se ha estudiado la posible relación entre la secreción de GHBP y el cáncer de seno.

El objetivo de este trabajo fue determinar el perfil electroforético de las proteínas de unión a $\mathrm{GH}$ y a PRL en suero de pacientes con cáncer de seno y en embarazo. Los resultados obtenidos permiten demostrar que no se presentan diferencias apreciables en el perfil electroforético para cada una de las muestras biológicas analizadas. Sin embargo, es necesaria su cuantificación y la de los niveles séricos de las hormonas para la elucidación de las funciones que estas dos proteínas lleven a cabo en los diferentes estados fisiológicos y patológicos.

\section{Agradecimientos}

El presente estudio fue financiado por el International Program in the Chemical Sciences (IPICS), Universidad de Uppsala (Suecia).

\section{Referencias}

1. Bazan JF. A novel family of growth factor receptors: a common binding domain in the growth hormone, prolactin, erythropoietin and IL-6 receptors, and the p75 IL-2 receptor beta-chain. Biochem Biophys Res Commun 1989;164:788-95.

2. Goffin V, Shiverick KT, Kelly PA, Martial JA. Sequence-function relationships within the expanding family of prolactin, growth hormone, placental lactogen, and related proteins in mammals. Endocr Rev 1996;17: $385-410$.

3. Ben-Jonathan N, Mershon JL, Allen DL, Steinmetz RW. Extrapituitary prolactin: distribution, regulation, functions, and clinical aspects. Endocr Rev 1996;17: 639-69.

4. Isacksson O, Edén S, Jansson J. Mode of action of pituitary growth hormone on target cells. Annu Rev Physiol 1985;47:483-99.

5. Kishimoto K, Tetsuya T, Shizuo A. Cytokine signal transduction. Cell 1994;76:253-62.

6. Bazan J. Structural design and molecular evolution of a cytokine receptor superfamily. Proc Natl Acad Sci USA 1990;87:6934-8.

7. Bazan J. Haemopoietic receptors and helical cytokines. Immunology Today 1990;11:350-4.

8. Kelly PA, Djiane J, Postel-Vinay MC, Edery M. The prolactin/growth hormone receptor family. Endocr Rev 1991;12:235-51.
9. Kelly PA, Ali S, Rozakis M, et al. The growth hormone/ prolactin receptor family. Recent Prog Horm Res 1993; 48:123-64.

10. Ross R, Esposito N, Shen X, et al. A short isoform of the human growth hormone receptor functions as a dominant negative inhibitor of the full-length receptor and generates large amounts of binding protein. Mol Endocrinol 1997;11:265-73.

11. Ross RJ. Truncated growth hormone receptor isoforms. Acta Paediatr 1999;88(Suppl.):164-6.

12. Darnell JE, Jr. The JAK-STAT pathway: summary of initial studies and recent advances. Recent Prog Horm Res 1996;51:391-403.

13. Heaney M, Golde D. Soluble cytokine receptors. Blood 1996;87:847-57.

14. Muller-Newen G, Kohne C, Heinrich P. Soluble receptors for cytokines and growth factors. Int Arch Allergy Immunol 1996;111:99-106.

15. Fernández-Botran R, Chilton $\mathbf{P}$, Ma Y. Soluble cytokine receptors: their roles in immunoregulation, disease and therapy. Adv Immunol 1996;63:269-336.

16. Mercado M, Baumann G. Growth hormone-binding proteins. The Endocrinologist 1993;3:268-77.

17. Baumann G. Editorial: Growth hormone binding proteinerrant receptor or active player? Endocrinology 1995;136:377-8

18. Herington A, Ymer S, Stevenson J. Identification and characterization of specific binding proteins for growth hormone in normal human sera. J Clin Investig 1986;77:1817-23.

19. Edens A, Southard J, Talamantes F. Mouse growth hormone-binding protein and growth hormone receptor transcripts are produced from a single gene by alternative splicing. Endocrinology 1994;135:2802-5.

20. Postel-Vinay MC, Belair L, Kayser C, Kelly PA, Djiane J. Identification of prolactin and growth hormone binding proteins in rabbit milk. Proc Natl Acad Sci USA 1991;88:6687-90.

21. Clandinin MT, Chappell JE, Mager D. Prolactin binding protein in human milk. Endocrinol Exp 1986;20: 209-15.

22. Cohen H, Cohen O, Gagnon J. Serum prolactin-binding protein (PRL-BP) of human and rat are identified as IgG. C R Acad Sci III 1994;317:293-8.

23. Cohen H, Guillaumot P, Sabbagh I. Characterization of a prolactin binding protein in rat serum. Endocrinology 1993;132:2601-6.

24. Emerman JT, Leahy M, Gout PW, Bruchovsky N. Elevated growth hormone levels in sera from breast cancer patients. Horm Metab Res 1985;17:421-4. 
25. Shiu RP. Prolactin receptors in human breast cancer cells in long-term tissue culture. Cancer Res 1979;39: 4381-6.

26. Vonderhaar BK. Prolactin: the forgotten hormone of human breast cancer. Pharmacol Ther 1998;79:16978.

27. Barnard R, Waters $\mathbf{M}$. The serum growth hormone binding protein: pregnant with posibilities. J Endocrinol 1997;153:1-14.

28. Bradford M. A rapid and sensitive method for the quantitation of microgram quantities of protein utilizing the principle of protein-dye binding. Anal Biochem 1976;72:248-54.

29. Maaskant RA, Bogic LV, Gilger S, Kelly PA, BryantGreenwood GD. The human prolactin receptor in the fetal membranes, decidua, and placenta. J Clin Endocrinol Metab 1996;81:396-405.

30. Baumann G, Stolar M, Amburn K, Barsano C, De Vries B. A specific growth hormone binding protein in human plasma: initial characterization. J Clin Endocrinol Metab 1986;62:134-41.

31. Habel LA, Stanford JL. Hormone receptors and breast cancer. Epidemiol Rev 1993;15:209-19.

32. Clevenger CV, Chang WP, Ngo W, Pasha TL, Montone KT, Tomaszewski JE. Expression of prolactin and prolactin receptor in human breast carcinoma. Evidence for an autocrine/paracrine loop. Am J Pathol 1995;146:695-705.

33. Decouvelaere C, Peyrat JP, Bonneterre J, Djiane $\mathbf{J}$, Jammes $\mathbf{H}$. Presence of the two growth hormone receptor messenger RNA isoforms in human breast cancer. Cell Growth Differ 1995;6:477-83.

34. Bulatov A, Martynov A, Smirnova N. Biochemical nature of high-molecular-weight prolactin of human serum: identification of a prolactin binding protein. Biochemistry (Moscow) 1997;62:1039-46.
35. Martini J, Pezet A, Guezennec C, Edery M, PostelVinay M, Kelly P. Monkey growth hormone $(\mathrm{GH})$ receptor gene expression. Evidence for two mechanisms for the generation of the $\mathrm{GH}$ binding protein. J Biol Chem 1997;272:18951-8.

36. Emtner M, Roos P. Identification and partial characterization of a growth hormone-binding protein in rat serum. Acta Endocrinol 1990;122:296-302.

37. Saito Y, Ikebuchi H, Yamazaki T, Sawada J. Release of a soluble form of growth hormone receptors (growth hormone binding proteins) from human IM-9 cells by proteolitic cleavage. J Biochem 1995;118:521-5.

38. Monsonego E, Baumbach W, Lavelin I, Gertler A, Hurwitz S, Pines M. Generation of growth hormone binding protein by avian growth plate chondrocytes is dependent on cell differentiation. Mol Cel Endocrinol 1997; 135:1-10

39. Amit T, Hacham H, Daily O, Hertz P, Barkey R, Hochberg Z. The Hep G2 cell line in the study of growth hormone receptor/binding protein. Mol Cel Endocrinol 1994;101:29-36.

40. Bick T, Amit T, Mansur M, Bar-Am O, Youdin M, Hochberg Z. Regulation of cellular rabbit growth hormone $(\mathrm{GH})$ receptor and $\mathrm{GH}$-binding protein generation in vitro. Endocrinol 1996;137:3977-85.

41. Clark RG, Mortensen DL, Carlsson LM, et al. Recombinant human growth hormone $(\mathrm{GH})$-binding protein enhances the growth-promoting activity of human GH in the rat. Endocrinol 1996;137:4308-15.

42. Ilkbahar Y, Wu K, Thordarson G, Talamantes F. Expression and distribution of messenger ribonucleic acid for growth hormone $(\mathrm{GH})$ receptor and $\mathrm{GH}$-binding protein in mice during pregnancy. Endocrinol 1995;136:386-92.

43. Forsyth IA. The mammary gland. Baillieres Clin Endocrinol Metab 1991;5:809-32. 